\title{
Drying Kinetics of Microwave-Dried Vegetable Amaranth (Amaranthus dubius) Leaves
}

\author{
Saheeda Mujaffar ${ }^{1} \&$ Alex Lee Loy ${ }^{1}$ \\ ${ }^{1}$ Food Science and Technology Unit, Department of Chemical Engineering, The University of the West Indies, St. \\ Augustine, Trinidad and Tobago, West Indies \\ Correspondence: Saheeda Mujaffar, Food Science and Technology Unit, Department of Chemical Engineering, \\ The University of the West Indies, St. Augustine, Trinidad and Tobago, West Indies. E-mail: \\ saheeda.mujaffar@sta.uwi.edu
}

Received: September 9, $2016 \quad$ Accepted: September 24, 2016 Online Published: October 13, 2016
$\begin{array}{ll}\text { doi:10.5539/jfr.v5n6p33 } & \text { URL: http://dx.doi.org/10.5539/jfr.v5n6p33 }\end{array}$

\begin{abstract}
The effect of microwave power level (200, 500, 700 and 1000W) on the drying behaviour of amaranth (Amaranthus dubius) leaves was investigated. Higher microwave power levels effected faster drying and there was an increase in drying rate constant $(k)$ as microwave power level increased from 200 to $1000 \mathrm{~W}$ and an increase in diffusivity $\left(D_{e f f}\right)$ values from $3.04 \times 10^{-10}$ to $2.82 \times 10^{-9} \mathrm{~m}^{2} / \mathrm{s}$. Leaves dried at $1000 \mathrm{~W}$ power level however showed noticeable scorching after 540s of drying. Drying at the lower microwave power levels occurred in the constant and falling rate period, while at the higher power levels drying occurred in the falling rate period after an initial warm-up phase. Amaranth leaves could be dried at $700 \mathrm{~W}$ power from an initial moisture content of $6.00 \mathrm{~g} \mathrm{H}_{2} \mathrm{O} / \mathrm{g} \mathrm{DM}(85.7 \% \mathrm{wb})$ to $0.08 \mathrm{~g} \mathrm{H}_{2} \mathrm{O} / \mathrm{g} \mathrm{DM}(7.6 \% \mathrm{wb})$ in $11.5 \mathrm{~min}$. Overall, of the twenty-two thin layer models applied to the $M R$ data, the Alibas model gave the best fit in terms of both the root mean square error (RMSE) and the chi-square statistic $\left(\chi^{2}\right)$.
\end{abstract}

Keywords: amaranth; microwave drying; Fick's Law; thin-layer modelling

\section{Introduction}

Vegetable amaranth (Amaranthus sp.) grows easily in the Caribbean and the edible portion (succulent leaves and young shoots) is widely used throughout the region as a cooked leafy vegetable. It is commonly called 'spinach' and 'chorai bhaji' in Trinidad and 'calalloo' in Jamaica. Vegetable amaranth (Amaranthus sp.) can also be used as a leafy green in salads and recipe preparations, often interchangeably with spinach, and is gaining popularity internationally as a less expensive option to kale. Amaranth leaves reportedly contain a high proportion of high quality protein, vitamins A and C, calcium, iron and fiber (Borneo \& Aguirre, 2008, Rodriguez, Perez, Romel, \& Dufour, 2011; Alegbejo, 2013; Andini, Yoshida, \& Ohsawa, 2013).

The postharvest life of amaranth greens is relatively short because of rapid wilting of the tender foliage. The leaves and soft leaf stalks are used within a few hours of purchase at produce markets or stored in polyethylene bags in refrigerated storage $\left(4^{\circ} \mathrm{C}\right)$ for use within one week. Like spinach leaves, drying of amaranth presents an opportunity to minimize wastage, preserve the leaves for future use, and add value by converting the leaves to a form that can be easily added to various food preparations. Dried amaranth flakes can potentially be used in various food preparations such as soups, sauces, dips and smoothies. Until recently, drying of vegetable amaranth leaves as a method to extend shelf-life was not widely investigated. Research works on dried amaranth have focused primarily on quality and nutrient content of the dried material (Fathima, Begum, \& Rajalakshmi, 2001; Rodriguez et al., 2011; Aletor \& Abiodun, 2013; Peter, Elizabeth, Judith, \& Hudson, 2014) and one study looked at the use of the ground, dried amaranth leaves in green pasta as a substitute for spinach (Borneo \& Aguirre, 2008). Published works on drying of vegetable amaranth are limited. Akonor \& Amankwah (2012) investigated the thin-layer drying kinetics of solar-dried Amaranthus hybridus leaves. The leaves were dried to a moisture content $8.5 \%$ (wb) over a period of two drying days. They reported a short sample heating phase and a short constant rate period followed by a falling rate period. An effective diffusivity $\left(D_{\text {eff }}\right)$ value of $1.95 \times 10^{-9}$ $\mathrm{m}^{2} / \mathrm{s}$ was reported and the Page model was found to best describe the moisture ratio data. The open sun drying of Amaranthus sp. was compared with drying in a greenhouse-type solar dryer (P. Singh, S. Singh, B.R. Singh, J. Singh and S.K. Singh, 2014). Leaves were subjected to three pre-treatments, namely magnesium chloride $(0.1 \%)$, 
sodium bicarbonate $(0.1 \%)$, and potassium metabisulfite $(2 \%)$. Drying curves were presented and moisture ratio values were tabulated. Pre-treated samples took less time to dry for both sun and solar-dried samples. Drying rates were higher in the greenhouse solar dryer. A short constant rate period was observed, based on the drying curves and they reported that the greenhouse dried samples were superior in quality.

There is a growing interest in microwave drying of leafy greens and herbs as a viable alternative to the conventional hot air drying method (Soysal, 2004; Ozbek \& Dadali, 2007; Alibas Ozkan, B. Akbudak \& N. Akbudak, 2007; Sharada, 2013). The main advantages of this drying method compared with hot air drying are a reduction in drying time, lower impact on product quality and less energy use (Zhang, Tang, Mujumdar \& Wang, 2006). Microwaves are a form of electromagnetic radiation that effect heating of foods by a process of dielectric heating (Decareau, 1985; Zhang et al., 2006). Based on previous work, the three common factors that would appear to have an impact on the drying rate and quality of microwave-dried leafy vegetables are microwave power level, loading density (sample size), and pre-treatments. With respect to microwave drying of amaranth in particular, documentation is limited but suggests the potential for this method of drying (Fathima et al., 2001; Rajeswari, Bharati, Naik \& Naganur, 2013). Fathima et al. (2001) investigated the quality of microwave drying of selected greens, including hot water-blanched amaranth leaves (Amaranth sp.). The maximum power output of the microwave oven and the loading density or sample size used were not disclosed. They reported that leaves could be dried in $12 \mathrm{~min}$ to a moisture value of $5 \%(\mathrm{wb})$. They noted that reconstituted amaranth leaves had acceptability scores similar to fresh leaves. Rajeswari et al. (2013) compared the quality and shelf life of pre-treated Amaranthus tricolor leaves (sample size not given) dried for $2 \mathrm{~h} 37 \mathrm{~min}$ at $60^{\circ} \mathrm{C}$ in a cabinet drier and $3 \mathrm{~min} 31 \mathrm{~s}$ in a microwave oven at $900 \mathrm{~W}$ power. The moisture content of microwave dried control samples averaged $3.12 \%$. Following drying, dehydrated leaves were packed in polypropylene pouches and stored in airtight aluminium containers for six months under ambient conditions. No works were found on the thin layer modelling of drying data of amaranth leaves.

The objective of this study was therefore to investigate the microwave drying of amaranth (Amaranthus dubius). Given the lack of information on the application of this drying method to this raw material, the work will follow the typical well-established approach to air drying kinetics (generation of drying curves, rate curves, effective diffusion coefficients and thin-layer modelling), as well as works done on microwave drying of spinach leaves and similar leafy vegetables and herbs. The objective of this study was to investigate the effect of microwave output power (200-1000W) on the drying behaviour of amaranth leaves, and model the drying data using twenty-two thin layer models.

\section{Method}

\subsection{Raw Material Handling and Preparation}

Amaranth shoots (Amaranthus dubius) was purchased at local market and stored at $4{ }^{\circ} \mathrm{C}$ in a refrigerator until use. Prior to drying, the leaves with petioles left intact were separated from the main hardy stems (Dadali et al., 2008) using a pair of scissors. Leaves that were damaged or wilted were discarded and a total weight of $2 \mathrm{~kg}$ of leaves was used. The weight, length and width of leaves averaged $2 \mathrm{~g}, 11 \mathrm{~cm}$ and $6 \mathrm{~cm}$, respectively.

\subsection{Microwave Drying}

Drying was carried out using a 34L oven capacity Amana MCS10TS Menumaster Commercial digital microwave oven (Accelerated Cooking Products (ACP), Cedar Rapids, IA, USA) with the following technical features: $3.5 \mathrm{kV}, 1000 \mathrm{~W}, 120 \mathrm{~V}, 60 \mathrm{Hertz}$. Time and microwave output power adjustments were done via a digital control panel located at the front of the oven. A sample size of $20 \mathrm{~g}$ of leaves was selected as the amount that could be spread in a thin layer onto the sample plate. Preliminary experiments revealed that blanching resulted in deterioration of leaf quality during drying when compared with untreated leaves. Leaves were spread in single layer onto a ceramic plate and the total weight of the plate with the leaves was recorded before placing into the oven. Leaves were first dried at full power $(1000 \mathrm{~W})$ and at 30s intervals the plate with the sample taken out, quickly weighed and returned to the oven. Drying was continued until there was no further change in weight or until burning of leaves was observed. At the end of drying, leaves were allowed to cool, packaged in re-sealable plastic storage bags and stored in laboratory desiccators until analysis. The drying procedure was repeated at power levels $700 \mathrm{~W}, 500 \mathrm{~W}$ and $200 \mathrm{~W}$ and drying runs at each power level were repeated five (5) times.

\subsection{Analytical Methods}

Sample weights $(\mathrm{g})$ during microwave drying were recorded $(0.01 \pm 0.005 \mathrm{~g})$ using an Explorer Pro Balance, Model EP2102C (Ohaus Corporation, NJ, USA). Moisture content of the fresh and dried samples was done using a Halogen Moisture Analyzer HB43-S (Mettler Toledo-AG, Zurich, Switzerland) set at $105^{\circ} \mathrm{C}$. Water activity $\left(\mathrm{a}_{\mathrm{w}}\right)$ 
was measured using an Aqua Lab CX-2 1021 water activity meter (Decagon Devices Inco., Pullman, WA, USA). Surface colour of leaves was measured using a CR-410 Choma Meter (Konica Minolta Sensing Americas, Inc., NJ, USA). Hunter values $(L, a, b)$ were recorded in four samples. The maximum for " $L$ " value is 100 (white) and the minimum is zero (black). Positive " $a$ " value is red, negative " $a$ " is green, while positive " $b$ " value is yellow and negative " $b$ " is blue (Hunterlab, 2008). Hue angle $\left(^{\circ}\right)$, Chroma and Total colour difference ( $\triangle E$ ) between fresh and dried leaves were calculated as given in Equations 1 through 3.

$$
\begin{gathered}
\text { Hue }=\operatorname{Arctan}(b / a) \\
\text { Chroma }=\left(a^{2}+b^{2}\right)^{1 / 2} \\
\Delta E=\left[\left(L_{0}-L\right)^{2}+\left(a_{0}-a\right)^{2}+\left(b_{0}-b\right)^{2}\right]^{1 / 2}
\end{gathered}
$$

Energy consumption for microwave drying was obtained using Equation 4 (Hebbar, Vishwanathan \& Ramesh, 2004).

$$
E_{t}=P . t
$$

\subsection{Drying Data Analysis}

Drying data was analysed using the standard approach to drying studies, that is, the generation of drying curves, drying rate curves and moisture ratio $(M R)$ data. Moisture content $\left.\left(\mathrm{g} \mathrm{H}_{2} \mathrm{O}\right) / \mathrm{g} \mathrm{DM}\right)$ of the leaves during the drying process was back-calculated based on the final moisture content value at the end of drying (Mujaffar \& Sankat, 2005 ; 2014). Effective moisture diffusivity $\left(D_{e f f}\right)$ values were calculated based on Fick's Second Law of Diffusion and through the calculation of the Moisture Ratio $(M R)$ based on the first term of the solution by Crank (1975) in Equation 5. The drying rate constant $(k)$ was determined from a plot of $\ln M R$ versus time $(t)$ based on Equation 6 and the rate constants $(k)$ determined from the slopes were then used to calculate the diffusivity values (Equation 7), using $1 \mathrm{~mm}$ as the leaf thickness (Simha \& Gugalia, 2013).

$$
\begin{gathered}
M R=\left(M-M_{e}\right) /\left(M_{o}-M_{e}\right)=\left(8 / \pi^{2}\right) \exp \left[-\pi^{2} D_{e f f} t / 4 X^{2}\right] \\
M R=\left(M-M_{e}\right) /\left(M_{o}-M_{e}\right)=A e^{-k t} \\
k=\pi^{2} D_{e f f} / 4 X^{2}
\end{gathered}
$$

For this study, a total of twenty-two (22) empirical and semi-empirical thin layer models (Alibas, 2014; W. Silva, C. Silva, Gama and Gomes, 2014) were applied to the $M R$ data (Table 1). As is now a common practice in thin-layer drying studies, the performance (fit) of the models is assessed through the use of the coefficient of determination $\left(R^{2}\right)$, root mean square error $(R M S E)$ and the chi-square statistic $\left(\chi^{2}\right)$. Model fit was done using Curve Expert Professional software (Version 2.3), Version 2.3.0 (Hyams, 2016).

Table 1. Thin Layer Drying Models

\begin{tabular}{ll}
\hline Model name & Equation \\
\hline Newton & $M R=\exp (-k t)$ \\
Page & $M R=\exp \left(-k t^{n}\right)$ \\
Modified Page & $M R=\exp (-k t)^{n}$ \\
Henderson and Pabis & $M R=a \exp (-k t)$ \\
Modified Henderson and Pabis & $M R=a \exp (-k t)+b \exp (-g t)+c \exp (-h t)$ \\
Logarithmic & $M R=a \exp (-k t)+c$ \\
Two-Term & $M R=a \exp \left(-k_{0} t\right)+b \exp \left(-k_{1} t\right)$ \\
Two-Term Exponential & $M R=a \exp (-k t)+(1-a) \exp (-k a t)$ \\
Wang \& Singh & $M R=1+a t+b t^{2}$ \\
Verma & $M R=a \exp (-k t)+(1-a) \exp (-g t)$ \\
Hii & $M R=a \exp \left(-k t^{n}\right)+c \exp \left(-g t^{n}\right)$ \\
Midilli & $M R=a \exp \left(-k t^{n}\right)+b t$ \\
Peleg & $M R=1-(x /(a+b x))$ \\
Weibull distribution & $M R=a-b \exp \left(-k t^{n}\right)$ \\
Diffusion approach & $M R=a \exp (-k t)+(1-a) \exp (-k b t)$ \\
Aghbashlo et al. & $M R=-k_{1} t /\left(1+k_{2} t\right)$ \\
Logistic & $M R=a_{0} /((1+a \exp (k t))$ \\
Jena and Das & $M R=a \exp \left(-k t+b t^{1 / 2}\right)+c$ \\
Demir et al. & $M R=a \exp \left(-k t^{n}\right)+c$ \\
Simplified Fick's Diffusion (SFFD) equation & $M R=a \exp \left(-c\left(t / L^{2}\right)\right)$ \\
Modified Page Equation-II & $M R=\exp \left(-k\left(t / L^{2}\right)\right)^{n}$ \\
Alibas & $M R=a \exp \left(-k t^{n}+b t\right)+g$ \\
\hline
\end{tabular}




\subsection{Statistical Analysis}

Further Regression Analysis and ANOVA were carried out using GENSTAT statistical software (VSN International, Hampstead, UK) and Post hoc analysis carried out using "Rapid publication-ready MS-Word tables for one-way ANOVA" (Assaad, Hou, Zhou, Carroll \& Wu, 2015).

\section{Results and Discussion}

\subsection{Colour and General Observations}

Generally, as the leaves dried, they underwent changes such as a colour change to a lighter green, the development of a grassy, hay-like odour, and some yellowing. As drying proceeded, moisture was seen on the surface of the leaves followed by evaporation of this water as the leaves appeared to become more brittle in texture. The higher the power level, the faster the development of these changes. Leaves dried at 1000W were very brittle and smelled "cooked" after 4 min of drying and beyond 9 min were burnt. Leaves dried at 200W power level appeared soggy for most of the drying process. With the exception of leaves dried at $200 \mathrm{~W}$ microwave power level, fully dried leaves could be easily crushed into flakes by hand. From general observations, leaves dried at $700 \mathrm{~W}$ power appeared to have the most appealing appearance and texture. These leaves remained intact as whole leaves after drying, but could be easily crushed to flakes or blended to a powder. Zhang et al. (2006) noted cautioned that uneven heating and textural changes can occur during microwave drying alone and success of microwave heating with high moisture contents often depends on uniformity of heating. Excessive heating along edges and corners may also lead to overheating and possible scorching and development of off-flavours (Nijhuis et al., 1998).

Table 2 gives the colour attributes of fresh and dried leaves. There were significant differences $(p \leq 0.05)$ between fresh and dried leaves with regard to all colour attributes values. Overall, there was an increase in " $L$ " values in dried leaves at all power levels, indicating lightening of the leaves. With respect to " $a$ " values, leaves dried at the lower power levels (200 and 500W) were similar in value indicating that the change in greenness was not significant. Leaves dried at the higher power levels (700 and $1000 \mathrm{~W})$ showed higher negative " $a$ " values, indicating that the green colour intensified. Overall, there was an increase in " $b$ " values in dried leaves at all power levels, indicating yellowing of the leaves during microwave drying.

Table 2. Colour attributes of fresh and dried amaranth leaves.

\begin{tabular}{llllll}
\hline Attribute & Fresh & Dried 200W & Dried 500W & Dried 700W & Dried 1000W \\
\hline $\boldsymbol{L}$ & $27.89 \pm 0.439^{\mathrm{c}}$ & $34.64 \pm 0.336^{\mathrm{a}}$ & $31.56 \pm 1.06^{\mathrm{b}}$ & $33.65 \pm 1.07^{\mathrm{ab}}$ & $31.39 \pm 0.559^{\mathrm{b}}$ \\
$\boldsymbol{a}$ & $-5.852 \pm 0.424^{\mathrm{a}}$ & $-5.532 \pm 0.355^{\mathrm{a}}$ & $-5.852 \pm 0.169^{\mathrm{a}}$ & $-8.51 \pm 0.427^{\mathrm{b}}$ & $-7.725 \pm 0.33^{\mathrm{b}}$ \\
$\boldsymbol{b}$ & $6.928 \pm 0.331^{\mathrm{c}}$ & $12.09 \pm 0.305^{\mathrm{ab}}$ & $11.14 \pm 0.291^{\mathrm{b}}$ & $12.94 \pm 0.631^{\mathrm{a}}$ & $11.1 \pm 0.389^{\mathrm{b}}$ \\
Chroma & $9.071 \pm 0.524^{\mathrm{c}}$ & $13.3 \pm 0.398^{\mathrm{b}}$ & $12.59 \pm 0.304^{\mathrm{b}}$ & $15.49 \pm 0.761^{\mathrm{a}}$ & $13.52 \pm 0.508^{\mathrm{b}}$ \\
Hue & $-49.92 \pm 0.74^{\mathrm{a}}$ & $-65.48 \pm 1.07^{\mathrm{d}}$ & $-62.28 \pm 0.668^{\mathrm{c}}$ & $-56.69 \pm 0.0871^{\mathrm{b}}$ & $-55.19 \pm 0.212^{\mathrm{b}}$ \\
$\boldsymbol{\Delta} \boldsymbol{E}$ & Reference & $8.55 \pm 0.35^{\mathrm{a}}$ & $5.83 \pm 0.55^{\mathrm{b}}$ & $8.77 \pm 1.26^{\mathrm{a}}$ & $5.78 \pm 0.72^{\mathrm{b}}$ \\
\hline
\end{tabular}

Values are means \pm SEM, $\mathrm{n}=4$ per treatment group.

Means in a row without a common superscript letter differ $(P<0.05)$ as analyzed by one-way ANOVA and the LSD test.

The change in " $L$ " values are an indicator for measuring browning and the change in " $b$ " values may be due to decomposition of chlorophyll and carotenoid pigments, non-enzymatic Maillard browning and formation of brown pigments (Dadali, Demirhan, \& Ozbek, 2007b). Di Cesare, Forni, Viscardi and Nani (2003) reported higher chlorophyll levels in microwave-dried basil leaves compared with air-dried and freeze-dried samples, concluding that the green colour of the leaves was better preserved during microwave-drying. With respect to colour change during microwave-drying of spinach, Alibas Ozkan et al. (2007) observed a change in " $L$ ", " $a$ " and " $b$ " values, reported that the least changes were observed at a power level of $750 \mathrm{~W}$ as power increased from 90 to 1000W. As shown in this study, Shaw, Meda, Tabil and Opoku (2007) found that microwave-dried coriander leaves had higher " $L$ "" values compared with fresh leaves, indicating lightening of the leaves. Unlike what was found in this study, there was a decrease in " $a$ " "and " $b$ " values. Shaw et al. (2007) also noted that when compared with fresh leaves, the microwave-dried leaves had lower colour change index values compared with oven-dried samples. Dadali et al. (2007b) investigated the colour change kinetics of spinach undergoing microwave drying and reported that the values of " $L$ " and " $b$ " decreased, while values of " $a$ " and total colour change $(\Delta E)$ increased as leaves were dried. They reported that the changes in colour attributes depended on the ratio of microwave output power to sample amount. 


\subsection{Drying Curves}

Yield (\%) calculated using weight data averaged $16.6 \%$ for leaves dried at $200 \mathrm{~W}$ and between 15.5 and $14.5 \%$ for those dried at 500 to $1000 \mathrm{~W}$. Rajeswari et al. (2013) reported an average yield of $13.5 \%$ for amaranth leaves dried at $900 \mathrm{~W}$ power for $3.5 \mathrm{~min}$. As given in Table 3, as the power level decreased from 1000 to $700 \mathrm{~W}$, the time taken to attain equilibrium moisture content increased approximately 2 -fold from 7.3 to $11.5 \mathrm{~min}$. Further decreasing the power level to $500 \mathrm{~W}$ again effected a 2-fold increase in time, however, further decreasing from 500 to $200 \mathrm{~W}$ power resulted in a 7 -fold increase in drying time to $135.7 \mathrm{~min}$. The reduction in drying time with increased power level is documented for other leafy materials. Alibas Ozkan et al. (2007) also found a marked decline in drying time of spinach leaves, with the drying time obtained using $90 \mathrm{~W}$ power being 13.81 times longer than the process using 1000W power. Dadali, Demirhan, and Ozbek (2007a) reported that drying time of spinach leaves was reduced by $80.55 \%$ when a microwave power of $900 \mathrm{~W}$ was used instead of $180 \mathrm{~W}$. Sharada (2013) found the drying time of spinach leaves to be 2.86 times longer at $90 \mathrm{~W}$ power level compared with $350 \mathrm{~W}$. Similar results were also documented for parsley, mint and basil leaves (Soysal, 2004; Ozbek \& Dadali, 2007; Dermirham \& Ozbek; 2011).

Table 3. Moisture content and water activity values of microwave-dried amaranth

\begin{tabular}{llllll}
\hline & Fresh & Dried 200W & Dried 500W & Dried 700W & Dried 1000W \\
\hline $\left.\mathrm{MC}\left(\mathrm{g} \mathrm{H}_{2} \mathrm{O}\right) / \mathrm{g} \mathrm{DM}\right)$ & $6.00 \pm 0.19^{\mathrm{a}}$ & $0.14 \pm 0.01^{\mathrm{b}}$ & $0.04 \pm 0.05^{\mathrm{b}}$ & $0.08 \pm 0.004^{\mathrm{b}}$ & $0.10 \pm 0.01^{\mathrm{b}}$ \\
& $0.976 \pm 0.004^{\mathrm{a}}$ & $0.565 \pm 0.029^{\mathrm{b}}$ & $0.407 \pm 0.016^{\mathrm{c}}$ & $0.299 \pm 0.059^{\mathrm{d}}$ & $0.434 \pm 0.031^{\mathrm{c}}$ \\
$\mathrm{a}_{\mathrm{W}}$ & NA & $135.7 \pm 3.3^{\mathrm{a}}$ & $19.8 \pm 0.7^{\mathrm{b}}$ & $11.5 \pm 0.3^{\mathrm{c}}$ & $7.3 \pm 0.1^{\mathrm{d}}$ \\
\hline
\end{tabular}

Values are means \pm SEM, $\mathrm{n}=5$ per treatment group.

Means in a row without a common superscript letter differ $(P<0.05)$ as analyzed by one-way ANOVA and the LSD test.

Initial moisture content and water activity $\left(\mathrm{a}_{\mathrm{w}}\right)$ values of fresh amaranth leaves averaged $6.00 \mathrm{~g} \mathrm{H}_{2} \mathrm{O} / \mathrm{g} \mathrm{DM}(85.7 \%$ wb) and 0.976 , respectively. A plot of moisture content $\left(\mathrm{g} \mathrm{H}_{2} \mathrm{O} / \mathrm{g} \mathrm{DM}\right)$ versus time for leaves dried at the various microwave power levels are given in Figure 1.

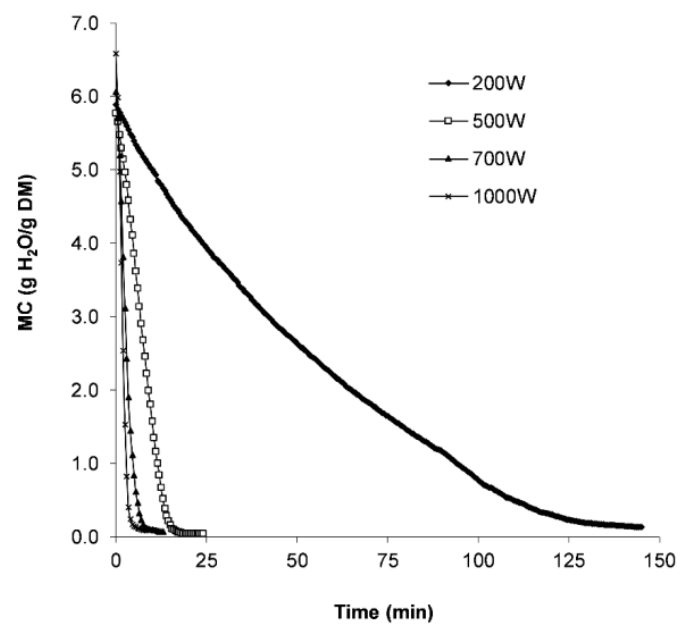

Figure 1. Effect of microwave power level on moisture content of amaranth leaves

Moisture content was significantly affected by drying time and microwave power level, as well as a time-power interaction $(p \leq 0.001)$. Increasing the power level from 200 to $500 \mathrm{~W}$ resulted in an increase in moisture reduction, however the greatest effect was observed as the power level increased from 200 to $500 \mathrm{~W}$. After 17 min of drying, the moisture values of samples dried at 200, 500, 700 and $1000 \mathrm{~W}$ averaged 4.45, 0.07, 0.08 and $0.10 \mathrm{~g} \mathrm{H}_{2} \mathrm{O} / \mathrm{g} \mathrm{DM}$, respectively.

The equilibrium moisture content and water activity values of microwave-dried samples are also given in Table 3 . Moisture values of dried samples were found to be significantly different from fresh leaves $(p \leq 0.001)$ but there was no effect of microwave power. Water activity values of dried samples were found to be significantly different from fresh leaves $(p \leq 0.001)$, and while there was a small treatment effect $(p \leq 0.05)$ there was no discernible trend. Equilibrium moisture content values for dried samples at $1000 \mathrm{~W}$ to $200 \mathrm{~W}$ microwave power levels ranged from 0.04 to $0.14 \mathrm{~g} \mathrm{H}_{2} \mathrm{O} / \mathrm{g} \mathrm{DM}$ ( $4.1 \%$ to $12.3 \% \mathrm{wb}$ ). Moisture values of leaves dried at $700 \mathrm{~W}$ power averaged $0.08 \mathrm{~g} \mathrm{H}_{2} \mathrm{O} / \mathrm{g} \mathrm{DM}(7-8 \% \mathrm{wb})$. 
The initial and equilibrium moisture content values and the effect of increasing microwave power level as seen in this study are in agreement with their results of studies done on the microwave drying and air of amaranth as well as spinach. Fathima et al. (2001) reported a moisture content of 5\% (wb) for hot water-blanched amaranth leaves (Amaranth sp.) dried at 100\% power (microwave wattage not given) for $720 \mathrm{~s}$. Rajeswari et al. (2013) compared the quality and shelf life of Amranthus tricolor leaves dried for $2 \mathrm{~h} 37 \mathrm{~min}$ at $60^{\circ} \mathrm{C}$ in a cabinet drier and $3 \mathrm{~min} 31 \mathrm{~s}$ in a microwave oven at $900 \mathrm{~W}$ power. The moisture content of microwave dried control samples averaged $3.12 \%(\mathrm{wb})$, while those of oven dried samples averaged $3.25 \%(\mathrm{wb})$. Singh et al. (2014) found the initial moisture content of amaranth leaves to average 6.55 to $7.27 \mathrm{~g} \mathrm{H}_{2} \mathrm{O} / \mathrm{g} \mathrm{DM}(87-88 \%$ wb) and microwave-dried untreated leaves to range from 0.05 to $0.06 \mathrm{~g} \mathrm{H}_{2} \mathrm{O} / \mathrm{g} \mathrm{DM}(5-6 \% \mathrm{wb})$.

In the present study the moisture content values of microwave-dried leaves after $11.5 \mathrm{~min}$ at $700 \mathrm{~W}$ power output are similar to those reported by Akonor and Amankwah (2012) for the solar drying of Amaranthus hybridus leaves. The initial moisture content of the leaves averaged $85.8 \%(\mathrm{wb})$ and leaves were solar-dried for two days to a final moisture content of $8.5 \%$ (wb). Singh et al. (2014) reported that a reduction in moisture content in amaranth leaves from 87.4 to $5.1 \%$ (wb) after 450 min of drying in a greenhouse-type solar dryer. Research work done on the microwave drying of spinach leaves also revealed that microwave power level had an important effect on moisture reduction, with higher moisture reduction at higher power levels (Alibas Ozkan et al., 2007; Dadali et al., 2007a; Sharada, 2013). For the microwave-drying of basil leaves, Seyedabadi (2015) noted that increasing microwave power increases the thermal gradient in the samples and thus increases evaporation rate, which results in faster drying. The drying time of basil leaves could be reduced by $82 \%$ by the application of $900 \mathrm{~W}$ power instead of $90 \mathrm{~W}$ power.

The drying energy consumption for $20 \mathrm{~g}$ samples of amaranth leaves are given in Figure 2. Energy consumption decreased as microwave power increased, with the most noticeable decline of 452 to 165 W.h occurring when microwave power increased from 200 to $500 \mathrm{~W}$. At power levels from 500 to $1000 \mathrm{~W}$, energy consumption values were not statistically different. Alibas Ozkan et al. (2007) also reported higher energy consumption values for leaves dried at lower power levels of 90 to $160 \mathrm{~W}$ microwave power levels, with values at 350 to $1000 \mathrm{~W}$ power levels being similar to each other.

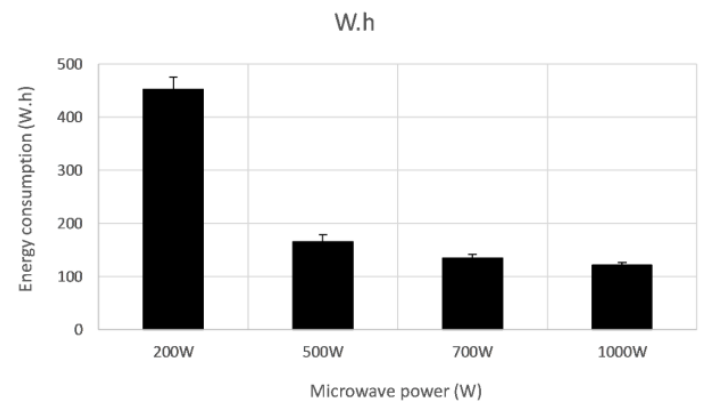

Figure 2. The drying energy consumption of amaranth leaves at different power levels.

\subsection{Drying Rate Curves}

Plots of drying rate (rate of change in moisture content) as a function of time and average moisture content are shown in Figure 3a and b, respectively. As shown in Figure 3a, the higher the microwave power level the higher the drying rate during the first 5 min of drying. Drying rates at 1000 and $700 \mathrm{~W}$ power levels increased rapidly during the first 90 s of drying, then decreased with time. For leaves dried at $500 \mathrm{~W}$ power, drying rate in increased gradually during the first $5 \mathrm{~min}$ of drying, remained steady for $5 \mathrm{~min}$, then declined. For leaves dried at $200 \mathrm{~W}$ power, rate was steady for the duration of the drying period. Drying rates after 1.75 min averaged $0.10,0.30$, 1.52 and $2.40 \mathrm{~g} \mathrm{H}_{2} \mathrm{O} / \mathrm{g} \mathrm{DM} / \mathrm{min}$ for leaves dried at 200, 500, 700 and $1000 \mathrm{~W}$, respectively.

Similar results were seen for microwave drying of spinach (Alibas Ozkan et al., 2007) who reported that the maximum moisture was removed between the first 120 to $150 \mathrm{~s}$ of drying at $1000 \mathrm{~W}$ microwave power, adding that about $60 \%$ of the drying process was completed by that time. At the lowest microwave power level of $90 \mathrm{~W}$, maximum drying rate of spinach leaves occurred after 270 s of drying, with $7.91 \%$ of the drying process being completed at that time.

As shown in Figure 3b, drying at 200W power level occurred mainly in the constant rate period. After an initial warm up period, drying at $500 \mathrm{~W}$ power level occurred in the constant rate period for the moisture content values between 4.5 to $1.0 \mathrm{~g} \mathrm{H}_{2} \mathrm{O} / \mathrm{g} \mathrm{DM}$, following which there was a falling rate period. For leaves dried at 700 and $1000 \mathrm{~W}$ power levels, there was an increase in drying rate at the start of drying between moisture levels of 6.5 to 
$4.5 \mathrm{~g} \mathrm{H}_{2} \mathrm{O} / \mathrm{g}$ DM. At moisture values lower than 3.0 to $3.5 \mathrm{~g} \mathrm{H}_{2} \mathrm{O} / \mathrm{g}$ DM, drying occurred in the falling rate period. Similar changes in drying rate with time and with increasing microwave power levels were reported for spinach, mint and parsley leaves (Soysal, 2004; Alibas Ozkan et al., 2007; Ozbek \& Dadali, 2007; Sharada, 2013). According to those authors, high moisture values of leaves at the initial stages of drying results in higher absorption of microwave power and higher drying rates due to higher moisture diffusion. Decrease in moisture as drying progresses results in a decrease in absorption of microwaves, a drop in temperature, and therefore a fall in drying rate.
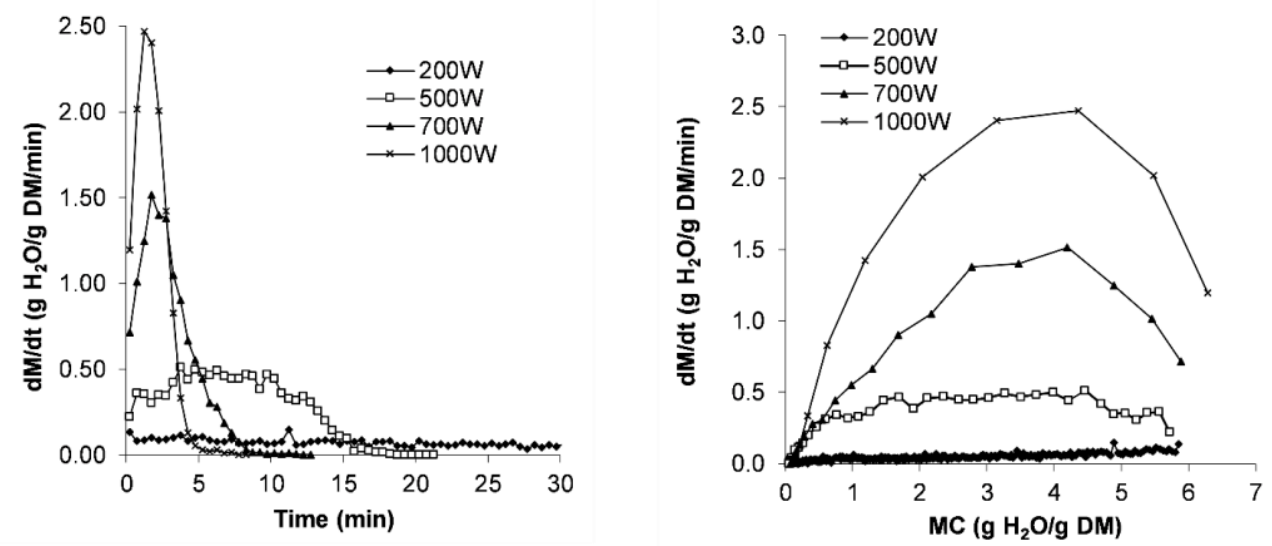

Figure 3. Drying rate curves of amaranth leaves at various microwave power levels

Constant rate drying has also been reported by some authors for the microwave drying of leafy materials. Soysal (2004) also found that constant rate drying dominated the drying time of parsley leaves dried at 360-900W power levels, with the critical moisture content averaging $1.75 \mathrm{~g} \mathrm{H}_{2} \mathrm{O} / \mathrm{g}$ DM. For grape leaves (Alibas, 2014), constant rates of drying occurred at higher moisture values, with the critical moisture content (start of the falling rate period) averaging $2.5 \mathrm{~g} \mathrm{H}_{2} \mathrm{O} / \mathrm{g} \mathrm{DM}$, similar to what was found in this study. Ozbek and Dadali (2007) also observed a short warm-up phase at higher microwave power levels for the microwave-drying of mint leaves. Drying during the constant rate period is not unexpected during microwave drying, as the internal pressure gradient generated by the microwave field effectively pumps water to the surface, wetting the surface and the rate of drying is dependent upon the evaporation of this free moisture from the surface. Other authors have reported drying during the falling rate only for the drying of spinach and celery leaves (Alibas Ozkan et al., 2007; Demirham \& Ozbek, 2011). Demirham and Ozbek (2011) added that the critical moisture content was equal to the initial moisture content of celery leaves which meant that the microwave drying process at 180 to $900 \mathrm{~W}$ power levels was entirely controlled by mass transfer resistance.

\subsection{Drying Rate Constants $(K)$ and Diffusion Coefficients $\left(D_{\text {eff }}\right)$}

The drying rate constants $(k)$ for the initial minutes of microwave drying were determined from plots of the $\ln$ free moisture (ln $M R$ ) as a function of drying time. Drying rate constants (Table 4) were significantly different at the different power levels $(p \leq 0.001)$. There was a 4.5 -fold increase in drying rate constant $(k)$ as microwave power level increased from 200 to $1000 \mathrm{~W}$.

Table 4. Drying rate constants $(k)$ and diffusion coefficients $\left(D_{\text {eff }}\right)$ for microwave-dried amaranth leaves

\begin{tabular}{cccc}
\hline Microwave power level $(\mathbf{W})$ & $\boldsymbol{k}(\mathbf{1} / \mathbf{s})$ & ${ }^{\mathrm{a}} \boldsymbol{D}_{\text {eff }}\left(\mathbf{m}^{\mathbf{2}} / \mathbf{s}\right)$ & $\boldsymbol{R}^{\mathbf{2}}$ \\
\hline $\mathbf{2 0 0}$ & $0.0003 \pm 0.000^{\mathrm{a}}$ & $3.04 \times 10^{-10}$ & 0.9781 \\
$\mathbf{5 0 0}$ & $0.0012 \pm 0.0001^{\mathrm{a}}$ & $1.22 \times 10^{-10}$ & 0.9882 \\
$\mathbf{7 0 0}$ & $0.0125 \pm 0.0006^{\mathrm{b}}$ & $1.27 \times 10^{-9}$ & 0.9943 \\
$\mathbf{1 0 0 0}$ & $0.0278 \pm 0.0008^{\mathrm{c}}$ & $2.82 \times 10^{-9}$ & 0.9981 \\
\hline
\end{tabular}

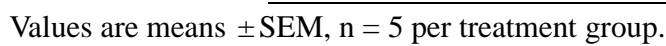

Means in a column without a common superscript letter differ $(P<0.05)$ as analyzed by one-way ANOVA and the LSD test.

${ }^{\mathrm{a}} \mathrm{D}_{\text {eff }}=\mathrm{k}\left(4 \mathrm{X}^{2} / \pi^{2}\right)$ where $\mathrm{X}=$ half thickness $0.05 \mathrm{~cm}$

With respect to drying rate constants reported in the literature, Dadali et al. (2007a) determined that for Spinacia oleracea $\mathrm{L}$. the drying rate constant determined using the Page model increased from 0.0436 to $0.3455 / \mathrm{min}$ as 
microwave output power increased from 180 to 900W while Alibas Ozkan et al. (2007) dried 50g samples and found the drying constants to increase from 0.0107 to $0.1283 / \mathrm{min}$ as microwave output power increased from 90 to $1000 \mathrm{~W}$. This trend is in agreement with that seen in this study. Diffusivity $\left(D_{\text {eff }}\right)$ values for amaranth leaves calculated from Equation 7 increased from $3.04 \times 10^{-10}$ to $2.82 \times 10^{-9} \mathrm{~m}^{2} / \mathrm{s}$. The low moisture diffusivity values of leaves dried at $200 \mathrm{~W}$ power level is expected, since these leaves looked moist for most of the drying process.

Simha and Gugalia (2013) found that the effective moisture diffusivity values $\left(D_{\text {eff }}\right)$ for Spinacia oleracea leaves dried at 180 and 300W microwave power levels ranged between 6.085 to $9.736 \times 10^{-9} \mathrm{~m}^{2} / \mathrm{s}$. Microwave-drying studies on Spinacia oleracea L. by Dadali et al. (2007a) and Alibas Ozkan et al. (2007) did not report on diffusivity values. With respect to $D_{\text {eff }}$ values for other microwave-dried leafy greens and herbs, Demirhan and Ozbek (2011) reported moisture diffusivity values for microwave-dried celery leaves of $0.343 \times 10^{-10}$ to $1.714 \mathrm{x}$ $10^{-10} \mathrm{~m}^{2} / \mathrm{s}$ as microwave power increased from 180 to $900 \mathrm{~W}$ using $25 \mathrm{~g}$ celery leaf samples. Alibas (2014) reported $D$-values for microwave-dried celery leaves ranging from $1.595 \times 10^{-10}$ to $6.377 \times 10^{-12} \mathrm{~m}^{2} / \mathrm{s}$ at power levels of 90 to $1000 \mathrm{~W}$. An increase with microwave power level has been attributed to the increased activity of water molecules at higher power levels.

\subsection{Thin Layer Models}

A plot of Moisture Ratio $(M R)$ versus time $(s)$ calculated based on Equation 6 is given in Figure 4. Moisture ratio values calculated for the falling rate period were significantly affected by drying time, microwave output power and a time-power interaction $(p \leq 0.001)$. A trend similar to the drying curves was observed, where increasing the power level from $200 \mathrm{~W}$ to $500 \mathrm{~W}$ effected a noticeable decline in moisture ratio. The moisture ratio values of leaves dried at $500 \mathrm{~W}$ power were similar to those dried at $700 \mathrm{~W}$ power. Further increasing the power level to $1000 \mathrm{~W}$ resulted in a slight decrease in moisture ratio values.

While no previous works were found on the moisture ratio curves of microwave-dried amaranth leaves, a greater decline in $M R$ values with increased microwave power level has been reported for other leafy materials including spinach, mint, celery and grape leaves, (Alibas Ozkan et al., 2007; Dadali et al., 2007a; Ozbek \& Dadali, 2007; Demirham \& Ozbek, 2011; Alibas, 2014). Dadali et al. (2007a) reported when microwave output power decreased from 900 to $180 \mathrm{~W}$ the time for the moisture ratio of spinach leaves to reach zero increased from 3.8 to 18 minutes, respectively.

With respect to drying of amaranth leaves by conventional drying methods, Akonor and Amankwah (2012) presented $M R$ curves for the drying of Amaranthus hybridus leaves during solar cabinet drying. They noticed a constant rate period preceding the falling rate period as evidenced by an "elbowing" of the moisture ratio curves at the start of the drying process.

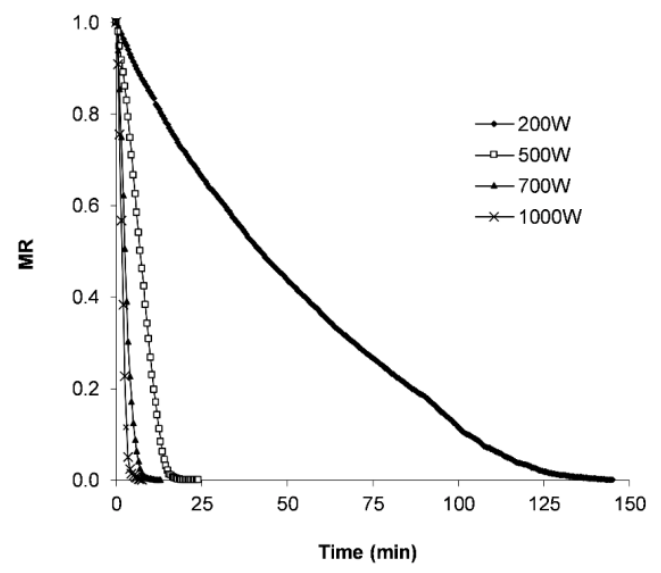

Figure 4. Moisture ratio curves for amaranth leaves at different microwave power levels

Many current drying studies also focus on the application of traditionally used thin layer models (empirical, semi-empirical and theoretical) to describe the moisture ratio $(M R)$ data. The performance (fit) of the models is assessed through the use of the coefficient of determination $\left(R^{2}\right)$, root mean square error $(R M S E)$ and the chi-square statistic $\left(\chi^{2}\right)$ as is the common practice in thin-layer drying studies. Of the twenty-two thin layer models applied to the MR data, the coefficients for the four models which best fit the data are given in Table 5 . Beyond these four models, the other models showed regression coefficients of less than 0.900 and some models simply failed. 
Table 5. Thin layer models and constants in order of best fit for amaranth leaves at different microwave power levels

\begin{tabular}{|c|c|c|c|c|c|c|c|c|c|c|c|}
\hline \multirow{2}{*}{ Power Level } & \multirow{2}{*}{ Model } & \multicolumn{7}{|c|}{ Model Constants } & \multirow[b]{2}{*}{$\mathbf{R}^{2}$} & \multirow[b]{2}{*}{ RMSE } & \multirow[b]{2}{*}{$\chi^{2}$} \\
\hline & & $\mathbf{k}$ & $\mathbf{n}$ & $\mathbf{a}$ & $\mathbf{b}$ & $\mathbf{k}_{1}$ & g & $\mathbf{k}_{2}$ & & & \\
\hline \multirow[t]{4}{*}{$200 W$} & Alibas & 0.9089 & 1.0054 & 1.0000 & 0.9246 & & -0.0140 & & 0.9962 & 0.021197 & 0.000654 \\
\hline & Aghbashlo et al. & & & & & 0.0060 & & -0.0022 & 0.9864 & 0.040117 & 0.001839 \\
\hline & Wang \& Singh & & & -0.0061 & & & & & 0.9785 & 0.050482 & 0.002912 \\
\hline & Peleg & & & 112.50 & 0.6654 & & & & 0.9423 & 0.082731 & 0.007822 \\
\hline \multirow[t]{4}{*}{$500 \mathrm{~W}$} & Alibas & 0.2425 & 1.0109 & 0.9867 & 0.2515 & & -0.0079 & & 0.9988 & 0.011230 & 0.000155 \\
\hline & Aghbashlo et al. & & & & & 0.0039 & & -0.0013 & 0.9922 & 0.028278 & 0.000864 \\
\hline & Wang \& Singh & & & -0.0037 & & & & & 0.9784 & 0.047107 & 0.002397 \\
\hline & Peleg & & & 166.38 & 0.7081 & & & & 0.9517 & 0.070417 & 0.005355 \\
\hline \multirow[t]{4}{*}{ 700W } & Aghbashlo et al. & & & & & 0.0013 & 0.0000 & -0.0007 & 0.9940 & 0.026533 & 0.000734 \\
\hline & Alibas & 0.9862 & 1.0004 & 1.1599 & 0.9870 & & -0.1120 & & 0.9863 & 0.040257 & 0.001805 \\
\hline & Wang \& Singh & & & -0.0016 & 0.0000 & & & & 0.9805 & 0.047931 & 0.002395 \\
\hline & Peleg & & & 562.19 & 0.5067 & & & & 0.9572 & 0.071050 & 0.005263 \\
\hline \multirow[t]{4}{*}{$1000 \mathrm{~W}$} & Alibas & 1.0350 & 1.0000 & 1.2535 & 1.0348 & & -0.2678 & & 0.9987 & 0.010268 & 0.000107 \\
\hline & Peleg & & & 3648.64 & 0.5420 & & & & 0.9984 & 0.011654 & 0.000137 \\
\hline & Wang \& Singh & & & -0.0002 & & & & & 0.9965 & 0.016924 & 0.000288 \\
\hline & Aghbashlo et al. & & & & & 0.0002 & & -0.0001 & 0.9959 & 0.018409 & 0.000341 \\
\hline
\end{tabular}

For leaves dried at 200, 700 and 1000W microwave power levels, the Alibas model (Alibas, 2012) gave the best fit in terms of both the root mean square error (RMSE) and the chi-square statistic $\left(\chi^{2}\right)$. At the 500W power level, the Alibas model was second best and a close second to the Aghbashlo et al. model. According to the author (Alibas, 2012), the Alibas model derived from the Midilli model. The constants ( $k$ and $n)$ as well as the coefficients $(a, b$ and $c$ ) depend on the operating conditions, which for microwave drying, includes the weight of the material and the microwave power level. Figure 5 gives the comparison of the predicted $M R$ values with the experimental values for all treatments based upon the Alibas model, and for the Aghbashlo et al. model for leaves dried at 500W power level.
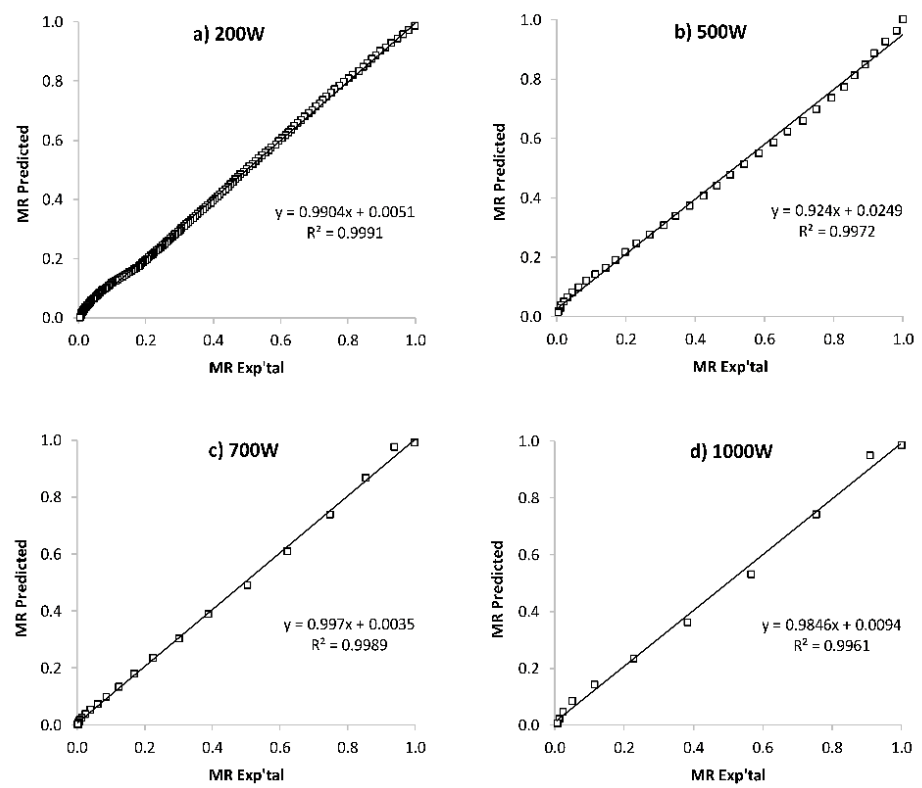

Figure 5. Comparison of predicted versus experimental moisture ratio values for amaranth leaves dried at different microwave power levels. Slope of straight line equations and high $R^{2}$ values give an indication of good agreement of values

No works were found on the modelling of microwave drying of amaranth leaves, however, Akonor and Amankwah (2012) modelled the data for the drying of Amaranthus hybridus leaves during solar cabinet drying using five well-known semi-empirical drying models. Based on the lowest RMSE and $\chi^{2}$ values, the Page model best fit the $M R$ data.

With regard to microwave drying of spinach leaves, Dadali et al. (2007a) reported when microwave output power decreased from 900 to $180 \mathrm{~W}$ the time for the moisture ratio of spinach leaves to reach zero increased from 
3.8 to 18 minutes, respectively. They tested the fit of eight thin layer drying models, and observed that the Page model was generally the most appropriate to describe the MR data. Alibas Ozkan et al. (2007) also presented plots of $M R$ versus time for microwave-dried Spinacia oleracea L. leaves dried at different power levels, reporting that the Page model adequately described the $M R$ data. Sharada (2013) found that out of four thin layer models (Newton, Henderson and Pabis, Midilli and Page) the Midilli model best described the microwave drying behaviour of spinach (Spinacia oleracea) leaves. Simha and Gugalia (2013) also found the Midilli model to best describe the drying data for microwave-dried Spinacia oleracea leaves.

With respect to the microwave drying of other leafy materials, Soysal (2004) gave $M R$ plots for microwave-dried parsley leaves and modelled the data using the Page model. Ozbek and Dadali (2007) presented similar MR plots for microwave-dried mint leaves, applying ten drying models and reporting the Midilli model as best describing the drying data. The Midilli model was also recommended for the modelling of $M R$ data for microwave-dried celery leaves (Demirham \& Ozbek, 2011). Seyedabadi (2015) found the logarithmic model to best describe drying data for basil leaves dried at 90 to $900 \mathrm{~W}$ microwave power levels.

\section{Conclusions}

From the results of this study, microwave drying appears to be a feasible drying method for the rapid drying of amaranth leaves. Microwave power level has a significant impact on the drying rates and quality of dried samples. An increase in power level resulted in more rapid drying, with the risk of scorching increasing at $1000 \mathrm{~W}$ power. Drying at $200 \mathrm{~W}$ power level was the least favourable drying treatment in terms of drying rate and overall appearance. The optimum drying power level based on drying rates and on quality and appearance of the leaves was found to be $700 \mathrm{~W}$ for a maximum of $11.5 \mathrm{~min}$ for $20 \mathrm{~g}$ samples. These leaves remained intact as whole leaves but could be easily crushed to flakes or blended to a powder. Drying at this microwave power level occurred in the falling rate period at moisture values below $4.5 \mathrm{~g} \mathrm{H}_{2} \mathrm{O} / \mathrm{g} \mathrm{DM}$, following an initial warm-up period. The drying data was successfully analysed through the use of a drying rate constant $(k)$ and moisture diffusivity $\left(D_{\text {eff }}\right)$ and the Alibas model successfully applied to the $M R$ data.

\section{Nomenclature}

\begin{tabular}{ll}
\hline$A$ & Drying constant \\
$a_{w}$ & Water activity \\
$D_{e f f}$ & Diffusion coefficient $\left(\mathrm{m}^{2} / \mathrm{s}\right)$ \\
$D M$ & Dry matter $(\mathrm{g})$ \\
$E_{t}$ & Energy consumption $(\mathrm{W} . \mathrm{h})$ \\
$F W$ & Fresh weight $(\mathrm{g})$ \\
$k$ & Drying rate constant $(1 / \mathrm{h})$ \\
$L_{0}, a_{0}, b_{0}$ & Colour attributes at time $=0$ \\
$L, a, b$ & Colour attributes at time $=\mathrm{t}$ \\
$M$ & Moisture content $\left(\mathrm{g} \mathrm{H}_{2} \mathrm{O} / \mathrm{g} \mathrm{DM}\right)$ at time $=\mathrm{t}$ \\
$M_{o}$ & Initial Moisture Content $\left(\mathrm{g} \mathrm{H} \mathrm{H}_{2} \mathrm{O} / \mathrm{g} \mathrm{DM}\right)$ \\
$M_{e}$ & Equilibrium Moisture Content $\left(\mathrm{g} \mathrm{H} \mathrm{H}_{2} \mathrm{O} / \mathrm{g} \mathrm{DM}\right)$ \\
$M R$ & Moisture Ratio \\
$P$ & Microwave power \\
$R^{2}$ & Coefficient of determination \\
$\mathrm{RMSE}$ & Root Mean Square Error \\
$X$ & Half-thickness of sample (m) \\
$k, k_{0}, k_{l}, a, b, c, g, n$ & Model constants \\
$t$ & Time (min) \\
$w b$ & Wet basis $\left(\mathrm{g} \mathrm{H}_{2} \mathrm{O} / 100 \mathrm{~g} \mathrm{FW}\right)$ \\
$\chi^{2}$ & Chi-Square \\
\hline &
\end{tabular}

\section{References}

Akonor, P., \& Amankwah, E. (2012). Thin layer drying kinetics of solar-dried Amaranthus hybridus and Xanthosoma sagittifolium Leaves. Journal of Food Technology, 10(3), 92-96. http://doi.org/10.4172/2157-7110.1000174

Alegbejo, J. O. (2013). nutritional value and utilization of amaranthus (Amaranthus spp.) - A Review. Bayero Journal of Pure and Applied Sciences, 6(1), 136-143. http://dx.doi.org/10.4314/bajopas.v6i1.27 
Aletor, O., \& Abiodun, A. R. (2013). Assessing the effects of drying on the functional properties and protein solubility of some edible tropical leafy vegetables, Research Journal of Chemical Sciences, 3(2), 20-26.

Alibas, I. (2014). Microwave, air and combined microwave-air drying of grape leaves (Vitis vinifera L.) and the determination of some quality parameters. International Journal of Food Engineering, 10(1), 69-88. http://10.1515/ijfe-2012-0037

Alibas, I. (2012). Microwave drying of grapevine (Vitis vinifera L.) leaves and the determination of some quality parameters. Journal of Agricultural Sciences, 18, 43-53.

Alibas Ozkan, I., Akbudak, B., \& Akbudak, N. (2007). Microwave drying characteristics of spinach. Journal of Food Engineering, 78(2), 577-583. http://doi.org/10.1016/j.jfoodeng.2005.10.026

Andini, R., Yoshida, S., \& Ohsawa, R. (2013). Variation in protein content and amino acids in the leaves of grain, vegetable and weedy types of amaranths. Agronomy, 3(2), 391-403. http://doi.org/10.3390/agronomy3020391

Assaad, H. I., Hou, Y., Zhou, L., Carroll, R. J., \& Wu, G. (2015). Rapid publication-ready MS-Word tables for two-way ANOVA. SpringerPlus, 4(1), 33. http://doi.org/10.1186/s40064-015-0795-z

Borneo, R., \& Aguirre, A. (2008). Chemical composition, cooking quality, and consumer acceptance of pasta made with dried amaranth leaves flour. LWT-Food Science and Technology, 41(10), 1748-1751. http://doi.org/10.1016/j.lwt.2008.02.011

Crank, J. (1975). The mathematics of diffusion (2nd ed.). UK: Oxford University Press.

Dadali, G., Demirhan, E., \& Ozbek, B. (2007a). Microwave heat treatment of spinach: drying kinetics and effective moisture diffusivity. Drying Technology, 25(10), 1703-1712. http://doi.org/10.1080/07373930701590954

Dadali, G., Demirhan, E., \& Ozbek, B. (2007b). Color change kinetics of spinach undergoing microwave drying. Drying Technology, 25(10), 1713-1723.

Dadali, G., Demirhan, E., \& Ozbek, B. (2008). Effect of drying conditions on rehydration kinetics of microwave dried spinach. Food and Bioproducts Processing, 86(4), 235-241. http://doi.org/10.1016/j.fbp.2008.01.006

Decareau, R. V. (1985). Microwaves in the food processing industry. Orlando: Academic Press Inc.

Demirhan, E., \& Ozbek, B. (2011). Thin-layer drying characteristics and modeling of celery leaves undergoing microwave treatment. Chemical Engineering Communications, 198(7), 957-975. http://doi.org/10.1080/00986445.2011.545298

Di Cesare, L. F., Forni, E., Viscardi, D., \& Nani, R. C. (2003). Changes in the chemical composition of basil caused by different drying procedures. Journal of Agricultural and Food Chemistry, 51, 3575-3581. http://10.1021/jf021080o

Fathima, A., Begum, K., \& Rajalakshmi, D. (2001). Microwave drying of selected greens and their sensory characteristics. Plant Foods for Human Nutrition, 56(4), 303-311. http://doi.org/10.1023/A:1011858604571

Hebbar, H.U., Vishwanathan, K. \& Ramesh, M. (2004). Development of combined infrared and hot air dryer for vegetables. Journal of Food Engineering 65(4):557-563. http://doi.org/10.1016/j.jfoodeng.2004.02.020

HunterLab (2008). Hunter L, a, b Color Scale. Application Note 8(9). Virginia, USA: Hunter Associates Laboratory Inc.

Hyams, D. G. (2016). CurveExpert Professional 2.3. http://www.curveexpert.net.

Mujaffar, S., \& Sankat, C. K. (2005). The air drying behaviour of shark fillets. Canadian Biosystems Engineering / Le Genie Des Biosystems Au Canada, 47, 11-21.

Mujaffar, S., \& Sankat, C. K. (2014). Modelling the drying behaviour of unsalted and salted catfish (Arius sp.) slabs. Journal of Food Processing and Preservation, 39 (6), 1385-1398. DOI: 10.1111/jfpp.12357

Nijhuis, H. H, Torringa, H. M., Muresan, S. Yuksel, D. Leguijt, C., \& Kloek, W. (1998). Approaches to improving the quality of dried fruit and vegetables. Trends in Food Science and Technology, 9, 13-20.

Ozbek, B., \& Dadali, G. (2007). Thin-layer drying characteristics and modelling of mint leaves undergoing microwave treatment. Journal of Food Engineering, 83(4), 541-549. http://doi.org/10.1016/j.jfoodeng.2007.04.004

Peter, C., Elizabeth, K., Judith, K., \& Hudson, N. (2014). Retention of $\beta$-carotene, iron and zinc in solar dried 
amaranth leaves in Kajiado County, Kenya., International Journal of Sciences: Basic and Applied Research (IJSBAR), 13(2), 329-338.

Rajeswari, R., Bharati, P., Naik, K. R., \& Naganur, S. (2013). Dehydration of amaranthus leaves and its quality evaluation. Karnataka Journal of Agricultural Sciences, 26(2), 276-280.

Rodriguez, P., Perez, E., Romel, G., \& Dufour, D. (2011). Characterization of the proteins fractions extracted from leaves of Amaranthus dubius (Amaranthus spp.). African Journal of Food Science, 5(7), 417-424

Seyedabadi, E. (2015). Drying kinetics modelling of basil in microwave dryer. Agricultural Communications, $3(4), 37-44$.

Sharada, S. (2013). Microwave drying of Spinacia oleracea, IJRET: International Journal of Research in Engineering and Technology, 2, 481-486.

Shaw, M., Meda, V., Tabil, J., \& Opoku, A. (2007). Drying and color characteristics of coriander foliage using convective thin -layer and microwave drying. Journal of Microwave Power \& Electromagnetic Energy, 41(2), 56-65.

Silva, W. P., Silva, C. M. D. P. S., Gama, F. J. a., \& Gomes, J. P. (2014). Mathematical models to describe thin-layer drying and to determine drying rate of whole bananas. Journal of the Saudi Society of Agricultural Sciences, 13(1), 67-74. http://doi.org/10.1016/j.jssas.2013.01.003

Simha, P., \& Gugalia, A. (2013). Thin layer drying kinetics and modelling of Spinacia oleracea leaves. International Journal of Applied Engineering Research, 8(9), 1053-1066.

Singh, P., Singh, S., Singh, B. R., Singh, J., \& Singh, S. K. (2014). The drying characteristics of amaranth leaves under greenhouse type solar dryer and open sun. Green Journal of Agricultural Sciences, 6(2014). http://doi.org/10.15580/GJAS.2014.6.040314174

Soysal, Y. (2004). Microwave drying characteristics of parsley. Biosystems Engineering, 89(2), 167-173. http://doi.org/10.1016/j.biosystemseng.2004.07.008

VSN International Limited (Rothamsted Experimental Station). (2011). GenStat Release 10.3 Discovery Edition.

Zhang, M., Tang, J., Mujumdar, A. S., \& Wang, S. (2006). Trends in microwave-related drying of fruits and vegetables. Trends in Food Science and Technology, 17(10), 524-534. http://doi.org/10.1016/j.tifs.2006.04.011

\section{Copyrights}

Copyright for this article is retained by the author(s), with first publication rights granted to the journal.

This is an open-access article distributed under the terms and conditions of the Creative Commons Attribution license (http://creativecommons.org/licenses/by/4.0/). 